\title{
THE POSSIBLE AMELIORATIVE EFFECT OF ZINC ON ALUMINIUM INDUCED THYROID TOXICITY IN RATS
}

\author{
$\mathcal{B Y}$ \\ Mohammed F. Abbas and Amr R. Zaki* \\ Forensic Medicine and Clinical Toxicology Department, \\ Faculty of Medicine-Minia University and Beni-Suef University ${ }^{*}$, Egypt.
}

\begin{abstract}
Aluminium (Al) is an environmental xenobiotic that induces disruption in pituitary-thyroid function. Zinc is essential for many biochemical processes and for cell proliferation. The aim of this study was to analyze the thyroid toxicity induced by Al in rats and to evaluate the possible ameliorative effect of zinc. The study was conducted on forty male albino rats randomly divided into 4 groups: control group, zinc group treated with zinc sulphate (2 $\mathrm{mg} / \mathrm{kg})$, Al group treated with $\mathrm{AlCl}_{3}(20 \mathrm{mg} / \mathrm{kg})$, and $\mathrm{AlCl}_{3}(20 \mathrm{mg} / \mathrm{kg})$ $+\mathrm{Zn}(2 \mathrm{mg} / \mathrm{kg})$ group. Rats were treated orally once daily for 30 consecutive days. At the end of the experiment, rats given aluminium alone had significantly higher MDA (malondialdehyde), superoxide dismutase in thyroid tissue and lower serum T3, T4 and TSH levels than the control group. Co-treatment of zinc with aluminium had an ameliorative effect on the previous parameters. Light and electronic microscopic investigations revealed that aluminium caused marked degenerative changes in the thyroid of rats. Restoration of the normal architecture of thyroid tissues were observed in rats received aluminium + zinc combination. Thus, aluminium can induce oxidative damage in rat thyroid and zinc has an ameliorative effect against this damage.
\end{abstract}

Keywords: Aluminium, thyroid toxicity, zinc, oxidative damage.

\section{INTRODUCTION}

Aluminium ( $\mathrm{Al})$ is an element widely spread in the environment and is one of the most abundant elements in the biosphere and causes adverse effects on various organs (Nday et al., 2010). Aluminium absorption/accumulation in humans can occur via food (food additives, food and beverage packaging, and cooking uten- sils), drinking water (municipal water treatment), and aluminum-containing medications (particularly antacid/ antiulcer and buffered aspirin formulations) (Reinke et al., 2003).

Toxicity of aluminum has been a matter of concern. High serum aluminum concentration was associated with dementia, anemia, osteoporosis, and abnormalities of 
thyroid function (Rosenlof et al., 1990). Aluminium is a disruptor of certain endocrine systems and classified as a metalloestrogen. Also, $\mathrm{Al}$ altered the pituitary endocrine regulation of thyroid gland and hormones (Darbre, 2005; Darbre, 2006).

Aluminium has a strong prooxidant activity in spite of its non-redox status. Aluminium caused tissue damage by generating reactive oxygen species (ROS) which causes lipid peroxidation (LPO) in different organs (Kumar and Gill, 2009).

Treatment of $\mathrm{Al}$ intoxication has primarily relied on chelation therapy. Moreover, chelating agents are incapable of removing metal from intracellular sites and may cause redistribution of the toxic metal and essential metal loss, resulting in poor clinical recovery (Flora and Pachauri, 2010).

Zinc is an important dietary component and it is the second most important transition metal after iron which possesses anticarcinogenic, anti-apoptotic properties. Zinc is an important element for cell proliferation and function (Singla and Dhawan, 2013; Adamo and Oteiza, 2010).

Zinc has some effects on thyroid hormone levels, as $\mathrm{Zn}$ supplementation improves thymic and immune functions (Bucci et al., 1999). Zinc possesses strong antioxidant activity in different organs
(Joshi et al., 2012).

The present study was done to analyze the thyroid toxicity induced by $\mathrm{Al}$ and to evaluate the possible ameliorative effect of zinc.

\section{MATERIALS AND METHODS}

\section{Animals:}

This work was carried out on 40 adult Wistar male albino rats (weighing approximately 200- $250 \mathrm{~g}$ ) of twelve weeks age. The animals were obtained from Minia University Laboratory Animals Growing Center. The rats were housed in plastic cages, fed a standard laboratory diet and water and maintained at a laboratory temperature of $22 \pm 3{ }^{\circ} \mathrm{C}$ and exposed to a 12 light, dark cycle. All aspects of animal care and treatment were carried out according to the local guide lines of the Ethical Committee of Faculty of Medicine- Minia University.

\section{Chemicals:}

Aluminium chloride was obtained from Al Safa Company (Minia-Egypt). Zinc sulphate was obtained from Sigma Pharmaceutical Company (Cairo-Egypt).

\section{Animal treatment schedule:}

The animals were divided into 4 groups each composed of 10 rats as follow:

Group (1) (control group): was fed a standard laboratory diet and water.

Group (2) $\left(\mathrm{ZnSo}_{4}\right.$ - treated group): rats 
were given $2 \mathrm{mg} / \mathrm{kg}$ daily orally for 30 days according to Goel et al. (2007).

Group (3) ( $\mathrm{AlCl}_{3}$-treated group): rats were given $\mathrm{AlCl}_{3}(20 \mathrm{mg} / \mathrm{kg}$ bw $)$ once daily orally for 30 days according to Krasovskii et al. (1979).

Group (4) $\left(\mathrm{ZnSo}_{4}+\mathrm{AlCl}_{3}\right.$ treated group): rats were given $\mathrm{ZnSo}_{4}$ by the same previous dose before $\mathrm{AlCl}_{3}$ administration by the same previous dose once daily orally for 30 days.

Doses were administered orally by oral gavage once daily for 30 consecutive days. Rats were sacrificed by decapitation after light ether anesthesia and dissected at the end of the experiment. All approved conditions used for animal housing and handling were considered. The experimental protocol used followed the regulations for administration and painless sacrifice of the experimental animals. The animals were acclimatized prior to starting dosing for a period of one week. The thyroid was dissected and subjected to light and electronic microscopic investigation. The remaining thyroid tissue was subjected to biochemical studies (malondialdehyde (MDA) and superoxide dismutase levels). Blood samples were collected for assaying the level of T3, T4 and TSH.

\section{Biochemical studies:}

After sacrification, blood samples were withdrawn from the retro-orbital plexus of veins using a capillary pipette and col- lected in heparinised tubes and centrifuged at $3000 \mathrm{rpm}$ for $15 \mathrm{~min}$. and stored at $-20{ }^{\circ} \mathrm{C}$ until required. The samples were subjected for the estimation of:

1- Serum total triiodothyronine (T3) and thyroxine (T4): using the radioimmunoassay kit purchased from Siemens Healthcare (United States). The method was carried out according to Hollander, 1971.

2- Serum thyroid stimulating hormone (TSH): by radioimmunoassay (Immunodiagnostic Systems Ltd., Liege, Belgium).

\section{Malondialdehyde (MDA) and superox-} ide dismutase assays:

Thyroids were dissected and separated and homogenized in 1:10 (wt: vol) $0.1 \mathrm{M}$ phosphate buffer ( $\mathrm{pH}$ 7.4) by the use of a Teflon headed homogenizer. Triton x100 and protease inhibitor cocktail were added. The homogenates were centrifuged at $6.000 \mathrm{~g}$ for $10 \mathrm{~min}$ at $4{ }^{\circ} \mathrm{C}$ and the supernatant was used to measure MDA and superoxide dismutase levels. All of the above parameters were obtained from Biodiagnostic Company, colorimetric method. MDA was measured as described by Yoshioka et al. (1979). Superoxide dismutase was measured as described by Kono (1978).

\section{Histopathological studies:}

Thyroids were removed and cut into small pieces about $1 \mathrm{~mm}$ thick. Some piec- 
es were fixed in $10 \%$ buffered formalin and processed for paraffin embedding by standard methods and sections of $6 \mu \mathrm{m}$ thicknesses were deparaffinized with $x y-$ lene and stained with hematoxylin-eosin to be viewed by Olympus light microscope (Olympus BX51, Tokyo, Japan) with an attached camera (Cannon 620) (Bancroft et al., 2002). Brightness, contrast were adjusted using Adobe Photoshop software.

For ultrastructural study, tissues were removed and placed in $2.7 \%$ glutaraldehyde- $0.1 \mathrm{M}$ phosphate buffer solution for $2 \mathrm{~h}$, and then flooded in 4 consecutive baths of the same fixative $0.15 \mathrm{M}$ phospate buffer $\left(4^{\circ} \mathrm{C}\right)$ for $1 \mathrm{~h}$ each. The samples were postfixed in a $2 \%$ osmic acid- $0.15 \mathrm{M}$ phosphate buffer solution $\left(4^{\circ} \mathrm{C}\right)$ for $1 \mathrm{~h}$, and again 4 times flooded in $0.15 \mathrm{M}$ phosphate buffer solution for $15 \mathrm{~min}$ each. Samples were acetone dehydrated, and embedded in polyesteric resin, polymerized at $60{ }^{\circ} \mathrm{C}$ for $72 \mathrm{~h}$ (Semithin sections $(1$ $\mu \mathrm{m})$ stained with toluidine blue. Ultrathin sections were made using ultramicrotome, and double contrasted with uranyl acetate and lead citrate solutions (Aguas, 1982), and examined by JEOL electron microscope (JEM-100CXII) equipped with a camera.

\section{Statistical analysis:}

Values were expressed as mean \pm standard deviation (SD). The data were ana- lyzed by using SPSS for windows (version 16.0). The significance of differences was calculated by using student $t$ - test. $\mathrm{P}<0.05$ was considered significant. One way ANOVA test with post Hoc LSD analysis was used for comparison between groups.

\section{RESULTS}

\section{Results of biochemical studies:}

Zinc-treated group did not differ significantly from the control one in terms of serum T3, T4 and TSH levels, but Al treated groups had significantly lower T3, T4 and TSH levels than the control group. However, the zinc plus Al-treated rats had significantly higher T3, T4 and TSH levels than the Al-treated group. Also results showed a significant decrease of $\mathrm{T} 3$ more than T4 in AL treated group (Table 1).

The control and zinc- treated rats had equivalent MDA level, but the $\mathrm{Al}$ and zinc plus Al- treated rats had significantly higher MDA level than the control group. However, the zinc plus Al- treated rats had significantly lower MDA level than the Al- treated rats (Table 2).

Zinc - treated group did not differ significantly from the control rats in terms of superoxide dismutase level, but $\mathrm{Al}$ and zinc plus $\mathrm{Al}$ - treated rats had significantly lower superoxide dismutase level when compared with the control rats. However, 
zinc plus $\mathrm{Al}$ - treated rats had significantly higher superoxide dismutase level when compared with the Al- treated group (Table 2).

\section{Histopathological findings in the thy- roid:}

The light microscopic examination of the thyroid of the control and zinc treated groups revealed normal structure of the thyroid which shows normal thyroid follicles lined with simple cuboidal epithelium and filled with colloid (Figure 1a).

Administration of zinc in group (4) restored the normal architecture of thyroid, only showing thyroid follicles of variable activity as some follicles are markedly distended. They are lined mainly by flat cells with flat nuclei. Other follicles appear normal and lined with simple cuboidal epithelium. The colloid has peripheral vacuolations (Figure 1b). The thyroid tissue of Al-treated group shows thyroid follicles of variable activity as most of follicles ap- pear involuted. These follicles have minimal amount of colloid, other follicles are distended with colloid. Some follicles have interrupted follicular wall and some have shedded epithelial lining (Figure $1 c)$.

Ultra structural analysis of thyroid tissues of the control and zinc-treated groups revealed normal architecture of thyroid tissue in which there is thyrocytes with normal rER and mitochondria. The nucleus appears euchromatic. Many apical microvilli are observed (Figure 2a). Ultrastructural examination of the thyroid tissues of zinc $+\mathrm{Al}$ treated group revealed that most thyroid tissue retained its near normal architecture (Figure 2b). Ultrastructural examination of thyroid tissues of Al-treated group revealed degenerated thyrocytes of a thyroid follicle. It shows dilated cisternae of rER with amorphous material. Also, there is degenerated mitochondria (faint matrix) and degenerated cytoplasm (Figure 2c). 
Table (1) : Student " $t$ " test statistical analysis of serum T3, T4 and TSH levels in different experimental groups $(\mathrm{n}=10)$.

\begin{tabular}{|c|c|c|c|c|}
\hline \multicolumn{5}{|c|}{ T3 level (mg/dl) } \\
\hline & $\begin{array}{c}\text { Group I } \\
\text { (control group) }\end{array}$ & $\begin{array}{c}\text { Group II } \\
\left(\mathrm{ZnSo}_{4}-\right. \\
\text { treated group) }\end{array}$ & $\begin{array}{c}\text { Group III ( } \mathrm{AlCl}_{3} \text {-treated } \\
\text { group) }\end{array}$ & $\begin{array}{c}\text { Group IV } \\
\left(\mathrm{ZnSo}_{4}+\mathrm{AlCl}_{3} \text { treated }\right. \\
\text { group })\end{array}$ \\
\hline Mean \pm SD & $50.08 \pm 10.5$ & $51.01 \pm 9.2$ & $36.22 \pm 6.8$ & $46.31 \pm 3.6$ \\
\hline Group I & & 0.796 & $<0.001 *$ & 0.297 \\
\hline Group II & & & $<0.001 *$ & 0.196 \\
\hline Group III & & & & $0.008 *$ \\
\hline \multicolumn{5}{|c|}{ T4 level (mg/dl) } \\
\hline & Group I & Group II & Group III & Group IV \\
\hline Mean \pm SD & $66.021 \pm 1.32$ & $66.00 \pm 1.3$ & $63.57 \pm 1.35$ & $66.01 \pm 1.31$ \\
\hline Group I & & 0.972 & $<0.001^{*}$ & 0.985 \\
\hline Group II & & & $<0.001 *$ & 0.987 \\
\hline Group III & & & & $<0.001 *$ \\
\hline \multicolumn{5}{|c|}{ TSH level (microU/dl) } \\
\hline & Group I & Group II & Group III & Group IV \\
\hline Mean \pm SD & $33.96 \pm 1.86$ & $33.56 \pm 1.6$ & $30.15 \pm 1.5$ & $32.5 \pm 1.85$ \\
\hline Group I & & 0.604 & $<0.001^{*}$ & 0.064 \\
\hline Group II & & & $<0.001 *$ & 0.174 \\
\hline Group III & & & & $0.004 *$ \\
\hline
\end{tabular}

One way ANOVA test with post Hoc LSD analysis, n: number, SD: standard deviation, *: significant at $\mathrm{p}<0.05$, T3: triiodothyronine, T4: thyroxine, TSH: thyroid stimulating hormone.

Table (2) : Student "t" test statistical analysis of MDA and SOD levels in different experimental groups $(\mathrm{n}=10)$.

\begin{tabular}{|c|c|c|c|c|}
\hline \multicolumn{5}{|c|}{ MDA level (mg/dl) } \\
\hline & $\begin{array}{c}\text { Group I } \\
\text { (control group) }\end{array}$ & $\begin{array}{c}\text { Group II } \\
\left(\mathrm{ZnSo}_{4}-\right. \\
\text { treated group) }\end{array}$ & $\begin{array}{l}\text { Group III ( } \mathrm{AlCl}_{3}- \\
\text { treated group) }\end{array}$ & $\begin{array}{c}\text { Group IV } \\
\left(\mathrm{ZnSo} 4^{-\mathrm{AlCl}_{3} \text { treated }}\right. \\
\text { group })\end{array}$ \\
\hline Mean \pm SD & $7.42 \pm 0.49$ & $7.07 \pm 0.47$ & $23.72 \pm 1.82$ & $12.73 \pm 0.83$ \\
\hline Group I & & 0.464 & $<0.001^{*}$ & $<0.001^{*}$ \\
\hline Group II & & & $<0.001 *$ & $<0.001 *$ \\
\hline Group III & & & & $<0.001 *$ \\
\hline \multicolumn{5}{|c|}{ SOD level (mg/dl) } \\
\hline & Group I & Group II & Group III & Group IV \\
\hline Mean \pm SD & $17.2 \pm 1.25$ & $17.32 \pm 1.27$ & $7.08 \pm 0.13$ & $14.04 \pm 0.92$ \\
\hline Group I & & 0.791 & $<0.001^{*}$ & $<0.001^{*}$ \\
\hline Group II & & & $<0.001 *$ & $<0.001 *$ \\
\hline Group III & & & & $<0.001 *$ \\
\hline
\end{tabular}

One way ANOVA test with post Hoc LSD analysis, n: number, SD: standard deviation, *: significant at $\mathrm{p}<0.05, \mathrm{MDA}$ : malondialdehyde, SOD: Superoxide dismutase. 

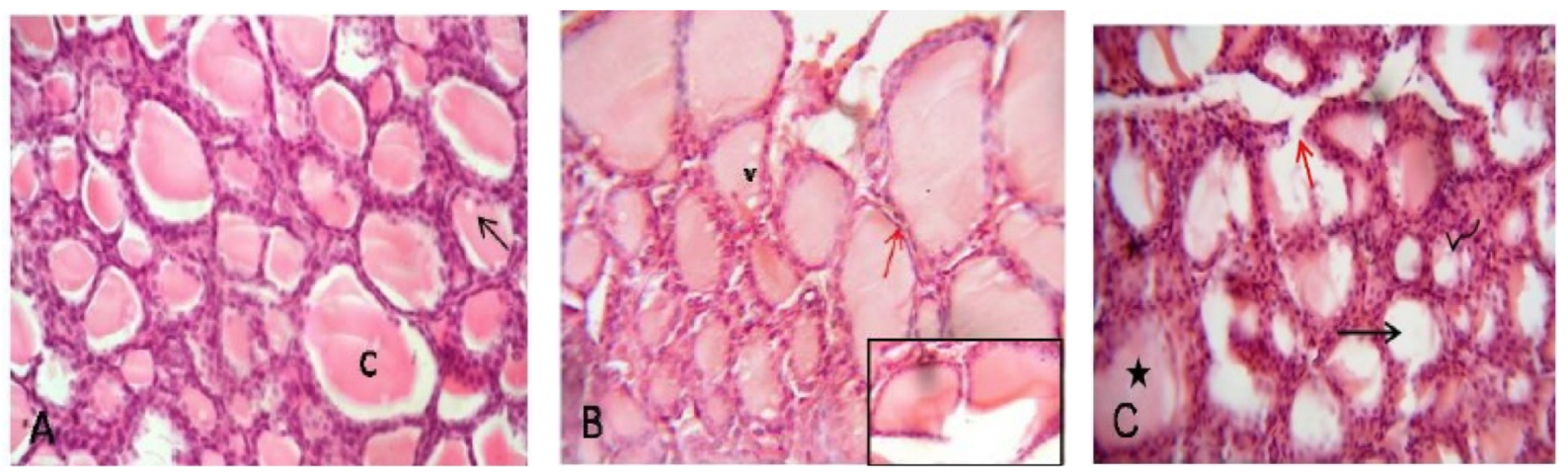

Fig. (1) Fig. (1a): Photomicrograph of section in the thyroid gland of groups I \& II (control \& Zn group) rat showing normal thyroid follicles lined with simple cuboidal epithelium and filled with colloid (C). The colloid (C) has peripheral vacuolations (arrow) (H\&E x 400). Fig. (1b): Photomicrograph of section in the thyroid gland of group IV (AL+Zn) showing thyroid follicles of variable activity as some follicles are markedly distended. They are lined mainlyby flat cells with flat nuclei (red arrow). Other follicles appear normal. They are lined with simple cuboidal epithelium. The colloid has peripheral vacuolations (V). Inset shows follicles with interrupted wall. Fig. (1c): Photomicrograph of section in the thyroid gland of group III (Al) shows thyroid follicles of variable activity as most of follicles appear involuted (black arrow). These follicles have minimal amount of colloid, other follicles are distended with colloid (star). Some follicles have interrupted follicular wall (red arrow). Some follicles have shedded epithelial lining (curved arrow) H\&E X400.
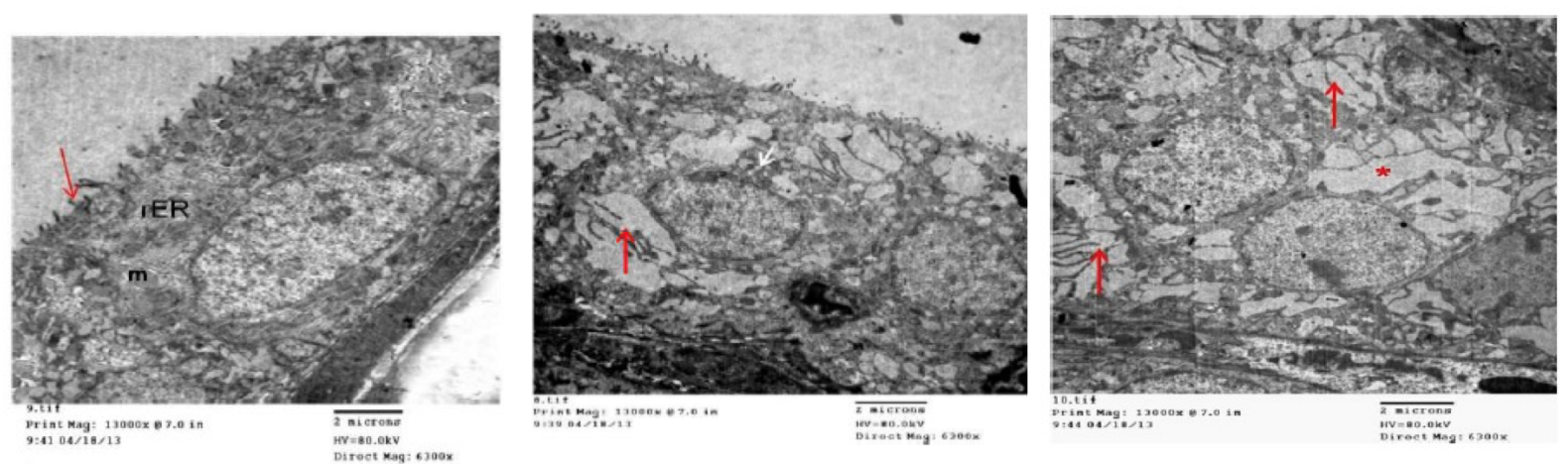

Fig. (1) Fig. (2a) : A photomicrograph of TEM section of the thyroid gland from a rat of the control and zinc group (I \&II) showing a thyrocytes with normal rough endoplasmic reticulum (rER) and mitochondria $(\mathrm{m})$. The nucleus appears euchromatic. Many apical microvilli are observed (arrow). Fig. (2 b): A Photomicrograph of TEM section of group III (AL) showing two degenerated thyrocytes with dilated cisternae of rER (red arrow) and some degenerated mitochondria (white arrow). Fig. (2c): A Photomicrograph of TEM section of group IV $(\mathrm{AL}+\mathrm{Zn})$ showing two degenerated thyrocytes of a thyroid follicle. It shows dilated cisternae of rER (arrows) with amorphous material $\left(^{*}\right)$. 


\section{DISCUSSION}

In recent years toxicity of Aluminium has been a matter of concern. However, studies on the endocrine tissues are limited. The aim of the current study focused on the possible protective role of $\mathrm{Zn}$ against deleterious effects of $\mathrm{Al}$ on the thyroid gland.

The results of this study revealed that Aluminium caused significant decreases in T3, T4 and TSH serum levels as compared to the control group. This effect might be happened through accumulation of the element in the thyroid and pituitary glands. These results were in harmony with a previous study, which showed that exposure to aluminum can disturb pituitary-thyroid function in rats and decrease T3, T4 and TSH (Zoeller, 2010). Another study showed that $\mathrm{Al}$ is a potent calcium channel blocker and therefore it inhibits both $\mathrm{TRH}$ and TSH release. This is because TRH uses both intracellular calcium stores and extra cellular calcium through voltage-dependent calcium channels to increase intracellular calcium concentration causing TSH secretion (Platt and Busselberg, 1994). Moreover, Liel et al. (1994) showed that high aluminum content in the diet may interfere with the entero-hepatic cycle of the thyroid hormones.
Also results showed a significant decrease of T3 level more than T4 level in Al treated group. T4 has a much longer half-life than T3 because of the tight binding of $\mathrm{T} 4$ to three principal binding proteins: thyroxine binding globulin (TBG), transthyretin (TTR) and albumin (Patrick and Altern, 2006).

Results revealed that Zinc supplementation counteract the thyroid toxicity of $\mathrm{Al}$ by elevated serum levels of T3, T4 and TSH near to the normal level. This result agree with Maxwell and Volpe (2007) who showed that zinc supplementation increased T3, T4 and TSH levels, and disagree with Faroogi et al. (2000) who showed decreased level of TSH on zinc supplementation.

Zinc effects on synthesis and mode of action of thyroid hormones are complex, as Zinc is an essential trace metal for catalytic activities of many enzymes involved in the metabolism of hormones (Arthur and Beckett, 1999), also zinc supplementation improves thymic and immune functions so it improved thyroid functions influencing the pituitary -thyroid axis (Napolitano et al., 1990; Bucci et al., 1999).

The protective role of zinc in thyroid gland related to the thyroid transcription factors which are essential for modulation 
of gene expression that contain zinc at cysteine residues and erythrocyte zinc levels could be used as an index of thyroid status (Civitareale et al.,1994). Also, Kralik et al. (1996) showed that zinc may be helpful in patients with low T3 due to its role in conversion of $\mathrm{T} 4$ to $\mathrm{T} 3$.

An antioxidant system is a crucial defense system against several diseases. Malondialdehyde (MDA) is the final decomposition product of lipid perioxidation and has a major contributor in the toxicity of many xenobiotics. Superoxide dismutase (SOD) is involved in the process of eliminating free radicals. Therefore, measuring the content of MDA and SOD activities can represent the oxidation level in tissues (Anane and Creppy, 2001).

The present study showed that the administration of $\mathrm{Al}$ induced an oxidative damage to thyroid and a state of oxidant/ antioxidant imbalance indicated by the significant increase in MDA level with a concomitant significant decrease in the activity of SOD. This was in accordance with previous studies which showed an increased levels of lipid peroxidation in Altreated animals due to presence of the cellular injury and the mitochondrial damage (Shati et al., 2011; Bizhanova and Kopp, 2009; Nehru and An and 2005).

Aluminium may not alone produce an increase in oxidative damage but it can increase the Fe-induced production of ROS, as the alterations in iron homeostasis, resulting in excessive free iron ions, which undergo the Fenton reaction. The Fenton reaction has importance in biology because of the creation of free radicals by chemicals that are present in vivo. Transition-metal ions such as iron and copper donate or accept free electrons via intracellular reactions and help in creating free radicals. Most intracellular iron is in ferric form and must be reduced to the ferrous form to take part in Fenton reaction. Finally superoxide ions and transition metals act in a synergistic manner to cause an oxidative damage (Kim et al., 2007; Sharma et al. 2007).

Also there is a reduction in the activity of SOD observed in this present study in AL group. This may be attributed to the reduced synthesis of these enzymes due to higher intracellular concentrations of $\mathrm{Al}$ and accumulation of free radicals. These findings agree with previous studies that reported $\mathrm{Al}$ induced free radicals and inhibited the antioxidant defense system by declining the expression of mRNA inside it (Newairy et al., 2009; Gonzalez et al., 2007). Also, SOD scavenging a large amount of reactive oxide species may result in the decrement of its activity (Wael et al., 2011). Moreover, AL increased thyroid thiobarbituric acid reac- 
tive substances (TBARS level), which indicating a certain degree of oxidative stress of thyroid tissue ( Exley, 2004; Suwalsky et al., 2004).

Finally the results showed that Zinc supplementation counteract the toxic effects of Aluminium on thyroid, since the levels of lipid peroxidation, in the combined $\mathrm{Al}$ and $\mathrm{Zn}$ group were found to be reduced compared to the group treated only with $\mathrm{Al}$ and levels of SOD in the combined $\mathrm{Al}$ and $\mathrm{Zn}$ group were found to be elevated compared to the group treated only with Al.

As zinc has an anti-peroxidative action against different metal toxicity (Mahboob et al., 2008), it stabilizes the structures of the membrane lipids and proteins by activating scavenging proteins (such as SOD) that in turn prevents lipid peroxidation and activates antioxidant enzymes (Klotz et al., 2003).

In addition, thyroid injury induced by Aluminium was confirmed by the observed histological alterations that include degenerative changes in thyroid gland. This result agree with Waring et al. (1996) who showed destruction, distortions of thyroglobulin in the thyroid follicles, also it was observed that some of the cells were lost of their nuclei and the cytoplasm, while the treatment of AL- administered rats with Zinc showed mild alterations which represented by vacuolated cytoplasm and minimal amount of colloid in some follicular cells. Overall, the administration of AL induced thyroid dysfunction which was ameliorated by the zinc treatment (Formigari et al., 2007).

\section{CONCLUSION}

It is clear that exposure to aluminum can disturb pituitary-thyroid function in rats, induce oxidative damage and inhibit the activities of antioxidant enzymes. In addition, it is evident that the use of $\mathrm{Zn}$ supplementation has produced beneficial effects in mitigating the toxic effects of $\mathrm{Al}$ on thyroid.

\section{ACKNOWLEDGEMENT}

All thanks and appreciations are to Dr/ Heba Tawfik for her assistance in doing the histopathological studies in this research.

\section{REFERENCES}

Adamo, A.M.; Oteiza, P.I. (2010): "Zinc deficiency and neurodevelopment: The case of neurons". BioFactors., 36: 117-124.

Aguas, P. (1982): "The use of osmium tetraoxide potassium ferrocyanide as an extracellular marker in electron microsco- 
py". Stain Technology, 57: 69-73.

Arthur, J.R.; Beckett, G.J. (1999): "Thyroid function". British Medical Bulletin, 55: 658-668.

Darbre, P.D. (2005): "Aluminium, antiperspirants and breast cancer". J. Inorg. Biochem., 99: 1912-1919.

Anane, R.; Creppy, E.E. (2001): "Lipid peroxidation as pathway of aluminum cytotoxicity in human skin fibroblast cultures: prevention by superoxide dismutase + catalase and vitamins $\mathrm{E}$ and $\mathrm{C}$ ". Hum. Exp. Toxicol., 20:477-481.

Bancroft, J.D.; Stevens, A.; Turner, D.R. (2002): Theory and practice of histological techniques. $4^{\text {th }}$ ed., New York: Churchill Livingstone, Ch. 3, P.P. 388564.

Bizhanova, A.; Kopp, P. (2009): "The sodium-iodide symporter NIS and pendrin in iodide homeostasis of the thyroid". Endocrinology, 150:1084-1090.

Bucci, I.; Napolitano, G.; Giuliani, C.; et al. (1999): "Zinc sulphate supplementation improves thyroid function in hypozincemic Down children". Biol. Trace Elem. Res., 67: 257-268.

Civitareale, D.; Saiardi, A.; Falasca, P.
(1994): "Purification and characterization of thyroid transcription factor 2". Biochem. J., 304: 981-985.

Darbre, P.D. (2006): "Metalloestrogens: an emerging class of inorganic xenoestrogens with potential to add to the oestrogenic burden of the human breast". J. Appl. Toxicol., 26: 191-197.

Darbre, P.D. (2005): "Aluminium, antiperspirants and breast cancer". J. Inorg. Biochem., 99: 1912-1919.

Douglas, W.W.; Rubin, R.P. (1963): "Mechanism of catecholamine release from the adrenal medulla and the role of calcium in stimulation secretion coupling". J. Physiol. (Lond.), 167:288.

Drury, R.A.; Wallington, E.A. (1980): Carleton's histological techniques. $5^{\text {th }}$ ed, Oxoford Univ. Press, London, New York, Tornodo., P.P. 241-242.

Exley, C. (2004): "The pro-oxidant activity of aluminum". Free Radic. Biol. Med., 36(3):380-387.

Faroogi, L.; Mazeto, GM.; Shuhama, T.; et al. (2000): "Effects of single venous dose of zinc on thyroid status in healthy individuals and patients with Graves' disease". Met. Based Drugs, 7:151-155. 
Flora, S.J.; Pachauri, V. (2010): "Chelation in metal intoxication". International Journal of Environmental Research and Public Health, 7: 2745-2788.

Formigari, A., P. Irato.; Santon, A. (2007): "Zinc, antioxidant systems and metallothionein in metal mediatedapoptosis: biochemical and cytochemical aspects". Comp. Biochem. Physiol. C. Toxicol. Pharmacol., 146:443-459.

Goel, A.; Chauhan, D.P.; Dhawan, D.K. (2000): "Protective effects of zinc in chlorpyrifos induced hepatotoxicity a biochemical and trace elemental study". Biol. Trace Elem. Res., 74:171-183.

Goel, A.; Dani, V.; Dhawan, D.K. (2007): "Zinc mediates normalization of hepatic drug metabolizing enzymes in chlorpyrifos-induced toxicity". Toxicol. Lett., 169:26-33.

Gonzalez, M.A.; Alvarez, M.L.; Pisani, G.B. (2007): "Involvement of oxidative stress in the impairment in biliary secretory function induced by intraperitoneal administration of aluminum to rats". Biol. Trace Elem. Res., 116:329-348.

Hollander, C.S.; Shenkman, L.; Mitsuma, T.; et al. (1971): "Hyper-triiodothyroninaemia as a premonitory manifestation of thyrotoxicosis". Lancet, 2(7727):
731-733.

Joshi, D.; Mittal, DK.; Shukla, S.; et al. (2012): "Therapeutic potential of $\mathrm{N}$-acetyl cysteine with antioxidants ( $\mathrm{Zn}$ and $\mathrm{Se}$ ) supplementation against dimethylmercury toxicity in male albino rats". Exp. Toxicol. Pathol., 64(1-2):103-108.

Kim, Y.; Olivi, L.; Cheong, J.H.; et al. (2007): "Aluminum stimulates uptake of nontransferrin bound iron and transferrin bound iron in human glial cells". Toxicol. Appl. Pharmacol., 220:349-356.

Klotz, L.O.; Kroncke, K.D.; and Sies, H. (2003): "Singlet oxygeninduced signaling effects in mammalian cells". Photochem. Photobiol. Sci., 2: 88-94.

Konno, T.; Kuriyama, K.; Hamaguchi, H.; et al. (1990): "Fenpyroximate (NNI850), a new acaricide". In proceedings of the Brighton Crop Protection Conference, Brighton, UK, Ed, P. 71.

Kralik, A.; Eder, K.; Kirchgessner, M. (1996): "Influence of zinc and selenium deficiency on parameters relating to thyroid hormone metabolism". Horm. Metab. Res., 28(5):223-226.

Krasovskii, G.N.; Vasukovich, L.Y.; Chariev, O.G. (1979): "Experimental study of biological effects of leads and alumi- 
num following oral administration". Environ. Health Perspect., 30:47-51.

Kumar, V.; Gill, K.D. (2009): "Aluminium neurotoxicity: Neurobehavioural and oxidative aspects". Arch. Toxicol., 83:965-978.

Klotz, L.O.; Kröncke, K.D.; Buchczyk, D.P.; et al. (2003): " Role of copper, zinc, selenium and tellurium in the cellular defense against oxidative and nitrosative stress". J. Nutr., 133: 1448-1451.

Liel, Y.; Sperber, A.D.; Shany, S. (1994): "Nonspecific intestinal adsorption of levothyroxine by aluminum hydroxide". Am. J. Med., 97(4):363-365.

Louis, W.C.; Williams, S.J. (1995): Neurotoxicology approaches and methods. Academic Press Inc., San Diego, NY, Toronto.

Mahboob, M.; Ogden, L.; Khan, A. (2008): "Zinc protected against lead induced changes in lipid peroxidation and antioxidative enzyme levels in CD1 mice liver brain and kidney". Toxicol. Int., 15: 37-41.

Marklund S.; Marklund G. (1974): "Involvement of the superoxide anion radical in the autoxidation of pyrogallol and convenient assay for superoxide dismutase". Eur. J. Biochem., 474:469474 .

Maxwell, C.; Volpe, S.L. (2007): " Effect of zinc supplementation on thyroid hormone function. A case study of two college females". Ann. Nutr. Metab., 51: 188194.

Morrissey, J.; Rothstein, M.; Mayor, G.; et al. (1983): "Suppression of parathyroid hormone secretion by aluminum". Kidney Int., 23(5):699-704.

Napolitano, G.; Palka, G.; Lio, S.; et al. (1990): "Is zinc deficiency a cause of subclinical hypothyroidism in Down syndrome"? Ann. Genet., 33:9-15.

Nday, C.M.; Drever, B.D.; Salifoglou, T., et al. (2010): "Zinc modulates aluminium-induced oxidative stress and cellular injury in rat brain". J. Inorg. Biochem. 104: 919-927.

Nehru, B.; Anand, P. (2005): "Oxidative damage following chronic aluminium exposure in adult and pup rat brains". J. Trace. Elem. Med. Biol., 19: 203-208.

Newairy, A.S.; Salama, A.F.; Hussien, H.M.; et al. (2009): "Propolis alleviates aluminum-induced lipid peroxidation and biochemical parameters in male rats". Food Chem. Toxicol., 47:1093-1098. 
Orihuela, D. (2009): "Inhibitory effect of aluminium on calcium absorption in small intestine of rats with different thyroid hormone status". J. Inorg. Biochem., 103:1542-1547.

Patrick, L. (2009): "Thyroid disruption: mechanisms and clinical implications in human health". Altern. Med. Rev., 14: 326-346.

Platt, B.; Busselberg, D. (1994): "Actions of aluminum on voltage-activated calcium channel currents". Cell Mol. Neurobiol., 14(6):819-829.

Reinke, CM.; Breitkreutz, J.; Leuenberger, H. (2003): "Aluminium in over-thecounter drugs: risks outweigh benefits"? Drug Saf. , 26(14):1011-1025.

Ribes, D.; Colomina, MT.; Vicens, P.; et al. (2010): "Impaired spatial learning and unaltered neurogenesis in a transgenic model of Alzheimer's disease after oral aluminum exposure". Curr. Alzheimer Res., 7:401-408.

Rosenlof, K.; Fyhrquist, F.; Tenhunen, R. (1990): "Erythropoietin, aluminium, and anaemia in patients on haemodialysis". Lancet, 335 (8684):247 -249.

Suwalsky, M.; Norris, B.; Villena, F.; et al. (2004): "Aluminum fluoride affects the structure and functions of cell membranes". Food Chem. Toxicol., 42: 925-933.

Singla, N.; Dhawan, D.K. (2013): "Zinc protection against aluminium induced altered lipid profile and membrane integrity". Food Chem. Toxicol., 55, 18-28.

Sharma, P.; Dubey, R.S. (2007): "Involvement of oxidative stress and role of antioxidative defense system in growing rice seedlings exposed to toxic concentrations of aluminum". Plant Cell Rep., 26: 2027-2038.

Shati, A.A.; Elsaid, F.G.; Hafez, E. E. (2011): "Biochemical and molecular aspects of aluminium chloride-induced neurotoxicity in mice and the protective role of Crocus sativus L. extraction and honey syrup". Neuroscience, 175, 66-74.

Song, Y.; Xue, Y.; Liu, X.; et al. (2008): "Effects of acute exposure to aluminum on blood-brain barrier and the protection of zinc". Neurosci. Lett., 445:42-46.

Wael, MES.; Mohamed, AAK.; Ashraf, MAM. (2011): "Prophylactic and therapeutic effects of taurine against aluminuminduced acute hepatotoxicity in mice". J. Hazard. Mater., 192:880-886.

Walker, V.R.; Sutton, R.A.; Meirav, O.; 
et al. (1994): "Tissue disposition of aluminum in rats measured by accelerator mass spectrometry". Clin. Invest. Med., 17 (5):420-425.

\section{Waring C.P.; Brown J.A.; Collins} J.E.; Prunet P. (1996): "Plasma prolactin, cortisol and thyroid responses of the brown trout (Salmo trutta) exposed to lethal and sublethal aluminium in acidic soft water". Gen Com. Endocr., 102: 377385.

Yagi, K. (1987): "Lipid peroxides and human disease". Chem. Phys. Lipids., 45:337-351.

Zoeller, T.R. (2010): "Environmental chemicals targeting thyroid". Hormones, 9: $28-40$. 


\title{
التاثيرالهحتمل للزنك على سميه الغدة الدرقية الهستحث

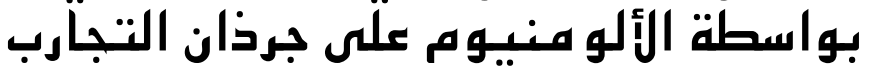

\author{
المشتركون فى البحث
}

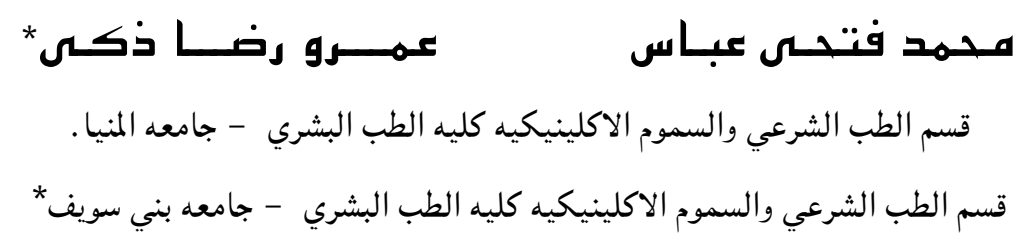

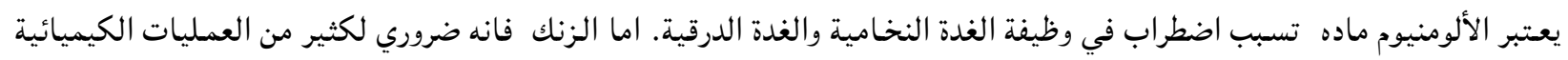

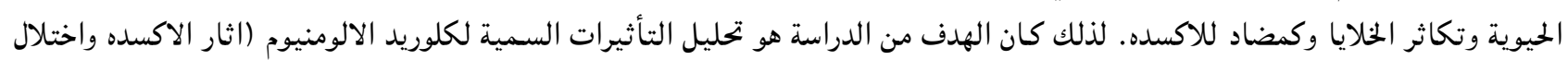

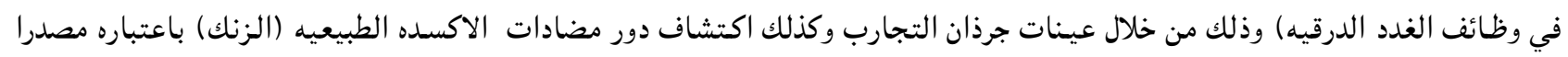

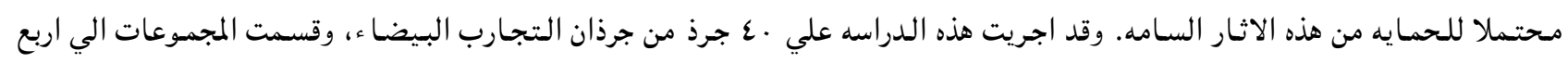

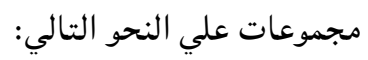
- المجموعه الضابطه السالبه: وهي مجموعه تعامل بالماء المقطر والطعام. - المجموعه الضابطه الموجبه: وهي مجموعه من الجرذان تعامل باضافه الزنك بآمجم/كجم. - المجموعه الثالثه و التي تعامل بالجرعه من كلوريد الالومنيوم ـبمجم /كجم. - المجموعه الرابعه و التي تعامل باضافه الزنك بعد المعامله بجرعه من كلوريد الالومنيوم بنفس الجرعات السابقه.

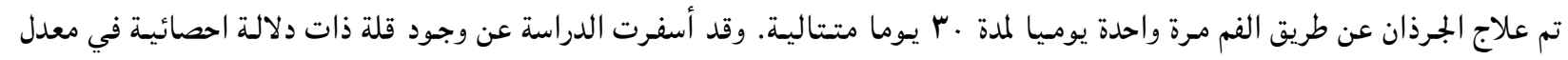

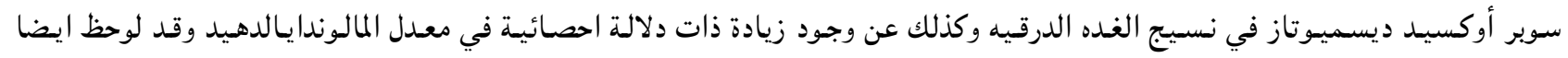

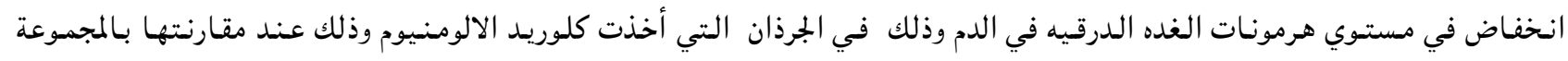

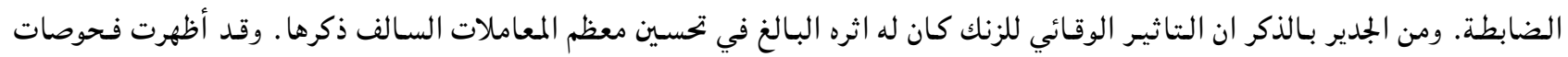

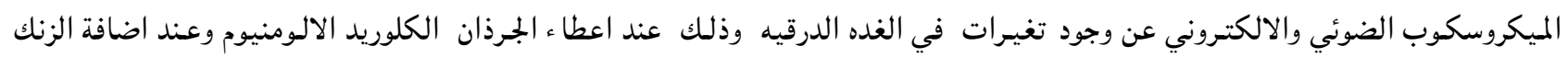

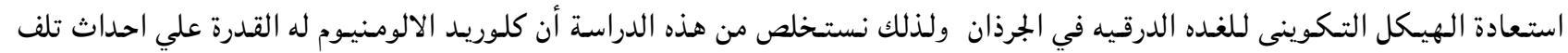

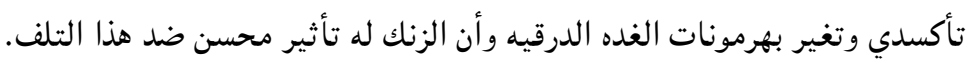

